\title{
Gender-Associated Behavior of Jordanians on Facebook
}

\author{
Raeda Tartory ${ }^{1}$ \\ ${ }^{1}$ Faculty of Arts and Sciences, Al-Ahliyya Amman University, Amman, Jordan \\ Correspondence: Raeda Tartory, Faculty of Arts and Sciences, Al-Ahliyya Amman University, Amman, Jordan. \\ E-mail: r.tartory@gmail.com
}

Received: January 16, 2019 Accepted: February 10, 2019 Online Published: March 2, 2019

doi:10.5539/ijel.v9n2p383

URL: https://doi.org/10.5539/ijel.v9n2p383

\begin{abstract}
Lack of sex-disaggregated data on internet and mobile phone access are among the key barriers to measure the progress in development goals that call for gender equality in access to the internet. Objective: The present study aims to investigate the language features that are used by females and males' friends when posting on their timelines on Facebook. The present study has employed cross-sectional design by collecting a sample of 270 randomly selected Facebook profiles using SurveyMonkey. Chi-square analysis has been used to analyze the conceptual framework. The study has found that the behavior of female users was much higher towards the communication features, language features, and social behavior as compared to the behavior of male users. The study enlarged into the understanding of Facebook as an online platform from the perspectives of Jordanian users. The study confirms the popularity of Facebook as an outlet of psychological and social expression for gender-associated behavior in the context of Jordan.
\end{abstract}

Keywords: communication behavior, language features, gender differences, Facebook, Jordan

\section{Introduction}

The gender-associated behavior has been studied as an interdisciplinary topic since many decades that include variety of fields like anthropology, biology, psychology, and social science. The gender differences, their origin, and its impact on individual's life have observed deviation between women and men and it is subject to debate among scholars (Psylla et al., 2017). The behavioral differences based on gender are reinforced by the values and cultural beliefs prevailing in the society that have been rooted in different biological roles. It has been shown that origination of gender-specific inequalities depends on biological predispositions that include brain structure and hormones, along with the organization of societies, where humans evolve (Schmitt et al., 2008; Wood, 2012). The cultural and societal explanations aggravate the gender differentiation that results in the development and maintenance of social ties in different ways (Stopczynski et al., 2014).

The impact of gender roles on the structuring and evolution of social interactions helps in understanding the study of social network. This helps in identifying and understanding the discrepancies to a larger extent; although, answers regarding the origins of gender differenced in social behavior are not provided. The individual-level characteristics have been found to relate strongly to social behavior that specifically include the psychological traits and mobility behavior within the cohort (Cho et al., 2011). It is important to evaluate the similarities and differences for the two gender groups with respect to the role played by social network. The presence of data gaps limits the ability of individuals to measure gender gaps in the access to internet and mobile phones, despite of increasing visibility of the issue

According to Broadband Commission (2013), it has been identified that lack of sex-disaggregated data on internet and mobile phone access are among the key barriers to measure the progress in development goals that call for gender equality in access to the internet. However, at the subnational level or by socio-demographic group (education or age), this data lacks granularities. Therefore, studies are needed to measure and track the current state of digital gender disparities in the context of this data sparse. In the similar context, the present study has leveraged Facebook as a source of digital trace data for measuring the gender differences in internet and mobile access in a global perspective. The present study aims to investigate the language features that are used by females and males' friends when posting on their timelines on Facebook. The study also explores and compares the communication between face to face interactions and on social networking communication to gain understanding of sociolinguistic behavior of both sexes on Facebook. The study results are likely to reveal 
differences and similarities between Facebook communication patterns of the participating males and females and the gender patterns established in the literature about face to face interactions.

The findings of the study will be of great use to providers of non-academic services, which are significant to Facebook users. These non-academic services include transport operators, entertainers, medical aid providers, and accommodation owners. This study has revealed that Arabs use Facebook to quest for information; thereby, service providers need to put platforms where they can search for relevant information. Therefore, there is a need for service providers to disseminate information from Facebook where there is high traffic and reach of Arabs. The findings of the study will also benefit social networking site operators, which revealed that the need to communicate positively and significantly impacts gender differences. Therefore, Facebook operators must put in platforms of features, which allow Arabs to communicate with the friends and family and to maintain existing relationships. Furthermore, this study can be used as a foundation for future studies who are interested in social networking sites and their uses.

\section{Empirical Framework}

Hitherto, gender differences and their influence on the use of internet and web-based applications have been focused by several studies. Thereby, this section is divided into three different themes, including communication behavior, language features, and social behavior that are affected based on the gender differences in terms of Facebook use. Gender possesses differentiated impact in various fields of psychology including the internet usage. In the social networks, Facebook is associated with large number of users depicting the best study pattern of the users' activities (Biernatowska et al., 2017). It has been observed that men are likely to possess increased frequency of internet use, broader range of online activities, and high intensity of use as compared to women. Thompson and Lougheed (2012) showed that there is much inequality in case of motives, activities, and perception of social media usage between men and women. The results showed that a high percentage of women spent their daily internet time on Facebook. Morris (2013) explored different pattern of communication established in face-to-face communication of the basis of gender differences. The gender differences either maintain or transform different communicational behaviors that engage the users on social networking site, like Facebook. The results showed that general patterns associated with communication behavior result in women to communicate in more interpersonally oriented ways; however, men need to communicate in more than one task individually in certain oriented way. Facebook is changing the nature of social relationships and online communication, as a growing part of media environment. Figure 1 has presented theoretical framework for this study showing the impact of gender differenced on the communication behaviors, language features, and social behaviors of the individuals.

\subsection{Communication Behavior and Facebook Usage}

Men \& Muralidharan (2017) have investigated and proposed a social media peer communication model for understanding social media dependency, public-organization social media, strength, and social media engagement. The findings of the study have revealed that public organization social engagement and tie strength are positively associated with peer communication regarding companies on social media. Kaya \& Bicen (2016) have aimed to explore the social media effects on the communicative behaviors while using Facebook. A total of 362 high school students have emphasized that Facebook is used for pictures and signs, sharing news, and communication entertainment. The study has also indicated that students were more concerned to protect their social identity as their Facebook sharing and communication is not public.

Aljasir et al. (2017) have reviewed that users' communication behavior on Facebook is concerned with self-disclosure and status updates. The study has also indicated that communication behavior of users is solely based on the selection and use of the media, which leads them to achieve their goal-directed objective. Paul, Puscher \& Strufe (2015) have focused on the understanding of behavioral assumptions on the sharing amongst users and communication patterns for enhancing the performance of social platforms. The application instances of different users can allow them to communicate with each other on the basis of the platform functionality. Vevere (2015) has shown that students identify the influence of social media on their daily communication patterns and behaviors, which include the situation and assume it as a new natural communication environment.

$\mathbf{H}_{01}$ : There is a positive impact of communication behavior on the gender differences.

$\mathbf{H}_{\mathbf{a} 1}$ : There is a negative impact of communication behavior on the gender differences.

\subsection{Language Features and Facebook Usage}

The interaction among the subjects reveals the patterns of a persuasive evaluation use as a consequence of the major use of social networking for creating community engagement and personal relationships. In this regard, 
Santamaría-García (2013) has indicated that Facebook changed the interaction of students for the particular objective to construct their personal relationships and identities. In addition, the study has revealed a positive contribution of Facebook in creating face and identity by a feeling of community and developing intimacy among students. Dino \& Gustilo (2015) have solely focused on the perceptions that Facebook language users are innovative and creative and; thereby, electronic English is an interesting variety of language. The study has indicated that there are different features used by Facebook users, which include code switching and acronym. Kasuma (2017) has indicated that students rely on the instructions of teachers to initiate the process, whereas they are in need of technological changes in learning. The structure of online group is negotiated through selective preferences in content and learning topics, demonstrating partial autonomy.

$\mathbf{H}_{02}$ : There is a positive impact of language features on the gender differences.

$\mathbf{H}_{\mathbf{a} 2}$ : There is a negative impact of language features on the gender differences.

\subsection{Social Behavior and Facebook Usage}

In the social circle, Facebook holds the biggest number of users. There is constant change in the social media resulting in the creation of new possibilities and redesigning of new possibilities. Previous studies have shown inequality between men and women considering their social behavior of social media usage. Women report that they spend more time on Facebook, as compared to men. The negative impact of using Facebook include; the feeling of stress, anxiousness, and addiction (Biernatowska et al., 2017). On the contrary, men are likely to use the social media sites for making friends, dating, learning about events, and discussing through internet (Muscanell \& Guadagno, 2012; Joiner et al., 2012).

$\mathbf{H}_{\mathbf{0 3}}$ : There is a positive impact of social behavior on the gender differences.

$\mathbf{H}_{\mathbf{a} 3}$ : There is a negative impact of social behavior on the gender differences.

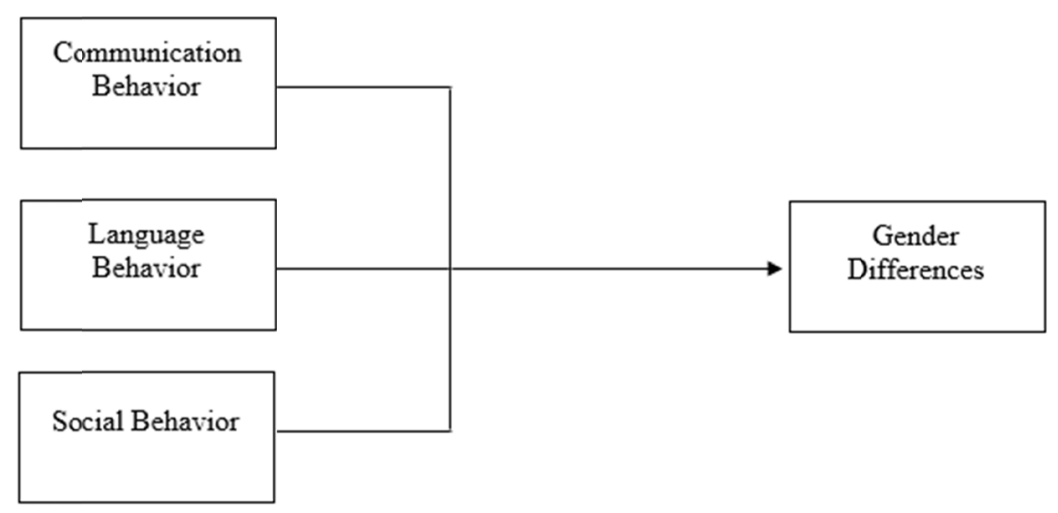

Figure 1. Conceptual framework

\section{Method}

\subsection{Study Design}

The present study has employed cross-sectional design by collecting a sample of 270 randomly selected Facebook profiles of the author's first and second degree connections who volunteered to fill the questionnaire attached in the Appendix A using SurveyMonkey. A total of 34 respondents were excluded as either the user's gender was not stated or the profile represented a company, rather than a personal profile.

\subsection{Study Variables}

The study has solely focused on three core variables, which include communication behaviors, language features, and social behavior. Communication behavior, language features, and social behavior are treated as independent variables; whereas, gender differences were treated as dependent variable.

\subsection{Study Tool}

A close-ended survey questionnaire has been used in this study to collect data from Facebook users in the region of Jordan. The questionnaire was divided into two sections, namely demographics and evaluation of gender differences. Gender and age were the demographic variables included in the first section. In the second section, 
each variable consists of 4 items to provide a comprehensive understanding of the survey questionnaire to the users. SurveyMonkey was used as a possible platform for collecting the data from Facebook users. Firstly, the questionnaire was uploaded on SurveyMonkey in Arabic language; however, was then translated at the time of analysis. A 5-point Likert scale has been used to measure the items listed for each variable in the questionnaire.

\subsection{Data Analysis}

A statistical package for social sciences (SPSS) has been used to analyze the data collected. The study has decided to provide descriptive statistics for gender and age whereas inferential statistics for the conceptual framework designed. Chi-square analysis has been used to differentiate communication behavior, language features, and social behavior based on the gender differences.

\subsection{Reliability and Validity}

The study has conducted a pilot study to assess the internal validity of the questionnaire. In this regard, a sample of 20 has been selected for the pilot study. Cronbach alpha has been used to measure the reliability of the questionnaire items. From the findings, the cronbach Alpha value was .787, which shows that the questionnaire items are well-designed to conduct further analysis (Table 1).

Table 1. Reliability statistics

\begin{tabular}{ll}
\hline Cronbach Alpha & No of Items \\
\hline .787 & 12 \\
\hline
\end{tabular}

\subsection{Ethical Considerations}

There were no ethical considerations present during the data collection process as the data was collected via online platform. Secondly, there was no item constructed that can harm self-esteem of the Facebook users in the questionnaire. All the participants have willingly participated in the study and responded to the questions accurately.

\section{Results}

This section has provided a comprehensive evidence of gender-associated behavior on Facebook based on descriptive and inferential statistics. Descriptive statistics present frequencies and percentages for the age and gender variables. Inferential statistics include Pearson correlation statistics and multiple regression analysis for proposed conceptual framework.

\subsection{Descriptive Statistics}

Table 2 has presented descriptive statistics for gender and age variables. A total of 110 male Facebook users $(40.7 \%)$ have participated in the online survey whereas 160 female Facebook users $(59.3 \%)$ took part in the online survey. Mostly Facebook users belong to the 26-30 age category (26.7\%) followed by $21-25$ age category (22.6\%), 15-20 age category (14.1\%), and 31-35 age category (12.2\%).

Table 2. Demographics

\begin{tabular}{llll}
\hline Gender & & & \\
\hline & & Frequency & Percent \\
\hline Valid & Male & 110 & 40.7 \\
& Female & 160 & 59.3 \\
& Total & 270 & 100.0 \\
\hline Age & & & \\
\hline & & Frequency & Percent \\
\hline Valid & 1 & .4 \\
& $15-20$ & 38 & 14.1 \\
& $21-25$ & 61 & 22.6 \\
& $26-30$ & 72 & 26.7 \\
& $31-35$ & 33 & 12.2 \\
& $40+$ & 33 & 12.2 \\
& $36-40$ & 32 & 11.9 \\
& Total & 270 & 100.0 \\
\hline
\end{tabular}


The comparison between gender-associated behavior and communication features has been presented in Table 3 . From the findings, it has been observed that female behavior tends to be higher as compared to male behavior towards the message deliverance while using Facebook. This association was also found to be significant at 5\% level of significance $(\mathrm{P}=0.006)$. Similarly, the findings have indicated that the behavior of female Facebook users was higher as compared to male Facebook users towards the thoughts sharing process while using Facebook. This association was also found to be significant at $5 \%$ level of significance $(\mathrm{P}=0.003)$. In addition, the behavior of male users was not higher as compared to female users when they use Facebook for communicating and connecting with their friends and family $(\mathrm{P}=0.005)$. Lastly, female users were found to be more spending time on Facebook as compared to male users $(\mathrm{P}=0.004)$.

Table 3. Comparison of gender-associated behavior with communication features

\begin{tabular}{|c|c|c|c|c|}
\hline & & Gender Behaviol & & P value \\
\hline \multirow{4}{*}{$\begin{array}{l}\text { FB helps to deliver } \\
\text { your message } \\
\text { successfully all the } \\
\text { time. }\end{array}$} & & Male Behavior & Female Behavior & \multirow{3}{*}{0.006} \\
\hline & Strongly Agree & $5(4.5 \%)$ & $7(4.4 \%)$ & \\
\hline & Agree & $45(40.9 \%)$ & $63(39.4 \%)$ & \\
\hline & Neutral & $33(30 \%)$ & $58(36.2 \%)$ & \multirow{8}{*}{0.003} \\
\hline \multirow{6}{*}{$\begin{array}{l}\text { FB helps to convey } \\
\text { your thoughts easily. }\end{array}$} & Disagree & $20(18.2 \%)$ & $27(16.9 \%)$ & \\
\hline & Strongly Disagree & $7(6.4 \%)$ & $5(3.1 \%)$ & \\
\hline & Strongly Agree & $7(6.4 \%)$ & $10(6.2 \%)$ & \\
\hline & Agree & $48(44 \%)$ & $81(50.6 \%)$ & \\
\hline & Neutral & $27(24.8 \%)$ & $45(28.1 \%)$ & \\
\hline & Disagree & $18(16.5 \%)$ & $18(11.2 \%)$ & \\
\hline \multirow{6}{*}{$\begin{array}{l}\text { FB is a good platform } \\
\text { to communicate and } \\
\text { connect with your } \\
\text { friends and family. }\end{array}$} & Strongly Disagree & $9(8.3 \%)$ & $6(3.8 \%)$ & \\
\hline & Strongly Agree & $27(24.5 \%)$ & $35(21.9 \%)$ & \multirow[t]{5}{*}{0.005} \\
\hline & Agree & $49(44.5 \%)$ & 95 (59.4\%) & \\
\hline & Neutral & $13(11.8 \%)$ & $15(9.4 \%)$ & \\
\hline & Disagree & $13(11.8 \%)$ & $12(7.5 \%)$ & \\
\hline & Strongly Disagree & $8(7.3 \%)$ & $3(1.9 \%)$ & \\
\hline \multirow{5}{*}{$\begin{array}{l}\text { You have been } \\
\text { spending more time } \\
\text { communicating } \\
\text { through FB than } \\
\text { Face-to-face. }\end{array}$} & Strongly Agree & $13(11.9 \%)$ & $15(9.4 \%)$ & \multirow[t]{5}{*}{0.004} \\
\hline & Agree & $31(28.4 \%)$ & $40(25 \%)$ & \\
\hline & Neutral & $15(13.8 \%)$ & $22(13.8 \%)$ & \\
\hline & Disagree & $33(30.3 \%)$ & $64(40 \%)$ & \\
\hline & Strongly Disagree & $17(15.6 \%)$ & $19(11.9 \%)$ & \\
\hline
\end{tabular}

The comparison between gender-associated behavior and language features has been presented in Table 4. From the findings, it has been observed that female behavior tends to be higher as compared to male behavior when they witnessed any grammatical issues in their written work. This association was also found to be significant at $5 \%$ level of significance $(\mathrm{P}=0.001)$. Similarly, the findings have indicated that the behavior of female Facebook users was higher as compared to male Facebook users when they use Facebook and found a negative effect on their written work. This association was also found to be significant at $5 \%$ level of significance $(\mathrm{P}=0.035)$. In addition, the behavior of male users was higher as compared to female users when they think that new literacies associated with electronic media is reflected into written academic work or schools $(\mathrm{P}=0.046)$. Lastly, female users were found to have more positive effects of Facebook on their written work as compared to male users $(\mathrm{P}=$ $0.004)$. 
Table 4. Comparison of gender-associated behavior with language features

\begin{tabular}{|c|c|c|c|c|}
\hline & & Male Behavior & Female Behavior & P value \\
\hline \multirow{5}{*}{$\begin{array}{l}\text { Have you witnessed } \\
\text { any grammatical errors } \\
\text { in written work that } \\
\text { could be attributed to } \\
\text { Facebook-speak? }\end{array}$} & Strongly Agree & $16(14.5 \%)$ & $34(21.5 \%)$ & 0.001 \\
\hline & Agree & $46(41.8 \%)$ & $63(39.9 \%)$ & \\
\hline & Neutral & $30(27.3 \%)$ & $33(20.9 \%)$ & \\
\hline & Disagree & $15(13.6 \%)$ & $26(16.5 \%)$ & \\
\hline & Strongly Disagree & $3(2.7 \%)$ & $2(1.3 \%)$ & \\
\hline \multirow{5}{*}{$\begin{array}{l}\text { Do you think the } \\
\text { incorporation of } \\
\text { Facebook-speak, if } \\
\text { any, has a negative } \\
\text { effect on written work? }\end{array}$} & Strongly Agree & $21(19.3 \%)$ & $40(25.5 \%)$ & 0.035 \\
\hline & Agree & 47 (43.1\%) & $61(38.9 \%)$ & \\
\hline & Neutral & $19(17.4 \%)$ & $26(16.6 \%)$ & \\
\hline & Disagree & $20(18.3 \%)$ & $27(17.2 \%)$ & \\
\hline & Strongly Disagree & $2(1.8 \%)$ & $3(1.9 \%)$ & \\
\hline \multirow{5}{*}{$\begin{array}{l}\text { Do you think that new } \\
\text { literacies associated } \\
\text { with electronic media } \\
\text { (e.g. Facebook-speak, } \\
\text { SMS-speak) should be } \\
\text { reflected or integrated } \\
\text { into written academic } \\
\text { work at schools? }\end{array}$} & Strongly Agree & $4(3.6 \%)$ & $7(4.4 \%)$ & 0.046 \\
\hline & Agree & $56(36.4 \%)$ & $40(35.4 \%)$ & \\
\hline & Neutral & $31(28.2 \%)$ & $42(26.6 \%)$ & \\
\hline & Disagree & $30(27.3 \%)$ & $41(25.9 \%)$ & \\
\hline & Strongly Disagree & $5(4.5 \%)$ & $12(7.6 \%)$ & \\
\hline \multirow{5}{*}{$\begin{array}{l}\text { Do you think the } \\
\text { incorporation of } \\
\text { Facebook-speak, if } \\
\text { any, has a positive } \\
\text { effect on written work? }\end{array}$} & Strongly Agree & $42(36.4 \%)$ & $46(35.4 \%)$ & 0.004 \\
\hline & Agree & $29(28.2 \%)$ & $52(26.6 \%)$ & \\
\hline & Neutral & $25(27.3 \%)$ & $31(25.9 \%)$ & \\
\hline & Disagree & $10(4.5 \%)$ & $22(7.6 \%)$ & \\
\hline & Strongly Disagree & - & - & \\
\hline
\end{tabular}

The comparison between gender-associated behavior and social behavior has been presented in Table 5. From the findings, it has been observed that female behavior tends to be higher as compared to male behavior when they share information and resources with their friends $(P=0.040)$. Similarly, the findings have indicated that the behavior of female Facebook users and male Facebook users was equal when they find out people with common interests and to join groups with such people $(\mathrm{P}=0.046)$. In addition, the behavior of female users was higher as compared to male users when they follow the changes occurring in their daily lives $(P=0.039)$. Lastly, female users were found to keep track of innovations on the agenda as compared to male users $(\mathrm{P}=0.004)$.

Table 5. Comparison of gender-associated behavior with social behavior

\begin{tabular}{|c|c|c|c|c|}
\hline & & Male Behavior & Female Behavior & P value \\
\hline \multirow{5}{*}{$\begin{array}{l}\text { I use Facebook to } \\
\text { share information and } \\
\text { resources with my } \\
\text { friends. }\end{array}$} & Strongly Agree & $17(18.9 \%)$ & $26(19.3 \%)$ & 0.040 \\
\hline & Agree & $59(65.6 \%)$ & $81(60 \%)$ & \\
\hline & Neutral & $8(8.9 \%)$ & $22(16.3 \%)$ & \\
\hline & Disagree & $6(6.7 \%)$ & $6(4.4 \%)$ & \\
\hline & Strongly Disagree & & & \\
\hline \multirow{5}{*}{$\begin{array}{l}\text { I use Facebook to find } \\
\text { out people with } \\
\text { common interests and } \\
\text { to join groups with } \\
\text { such people. }\end{array}$} & Strongly Agree & $16(14.5 \%)$ & $16(10.1 \%)$ & 0.046 \\
\hline & Agree & $54(49.1 \%)$ & $69(43.4 \%)$ & \\
\hline & Neutral & $19(17.3 \%)$ & $30(18.9 \%)$ & \\
\hline & Disagree & $16(14.5 \%)$ & $35(22 \%)$ & \\
\hline & Strongly Disagree & $5(4.5 \%)$ & $9(5.7 \%)$ & \\
\hline \multirow{5}{*}{$\begin{array}{l}\text { I use Facebook to } \\
\text { follow the changes } \\
\text { occurring in our daily } \\
\text { lives. }\end{array}$} & Strongly Agree & $33(30 \%)$ & $38(24.1 \%)$ & 0.039 \\
\hline & Agree & $63(57.3 \%)$ & $89(56.3 \%)$ & \\
\hline & Neutral & $6(5.5 \%)$ & $19(12 \%)$ & \\
\hline & Disagree & $5(4.5 \%)$ & $7(4.4 \%)$ & \\
\hline & Strongly Disagree & $3(2.7 \%)$ & $5(3.2 \%)$ & \\
\hline \multirow{5}{*}{$\begin{array}{l}\text { I use Facebook to keep } \\
\text { track of innovations on } \\
\text { the agenda. }\end{array}$} & Strongly Agree & $17(18.9 \%)$ & $26(19.3 \%)$ & 0.004 \\
\hline & Agree & $59(65.6 \%)$ & $81(60 \%)$ & \\
\hline & Neutral & $19(17.3 \%)$ & $30(18.9 \%)$ & \\
\hline & Disagree & $5(4.5 \%)$ & $7(4.4 \%)$ & \\
\hline & Strongly Disgree & $3(2.7 \%)$ & $5(3.2 \%)$ & \\
\hline
\end{tabular}




\section{Discussion}

The study has revealed the impact of communication behavior, language features, and social behavior on gender differences among Arabic Facebook users. Moreover, chi-square analysis has been used to examine the impact of communication behavior, language features, and social behavior on gender differences. The findings have confirmed both hypothesis that there is a positive impact of both communication behavior, language features, and social behavior on gender differences. Previously, several studies have used these constructs and supported the findings of the present study (Aljasir et al., 2017; Biernatowska, Balcerowska, \& Bereznowski, 2017; Kasuma, 2017).

The results have shown a positive and significant impact of communication behavior on gender differences. These findings are in-line with the findings of past studies. For instance, Morris (2013) has shown that there were significant gender differences with respect to communication behaviors and Facebook usage. The study, using content analysis, has portrayed that users spending time on Facebook assisting comprehensively in their face-to-face communication. Women were more oriented towards the communication behaviors and this was also supported by the findings of the current study. Likewise, the findings of Brouer et al. (2017) was in support with the findings of the present study that the interaction of female Facebook users on Facebook is perceived as most hirable and attractive whereas male Facebook users were found to be less hirable and attractive. This shows the influence and communication bridging of female users on Facebook with their colleagues, family, and friends.

The findings of the present study have shown a positive and significant impact of language features on gender differences. In addition, the findings have indicated positive impact of grammatical mistakes and Facebook-speak on male and female Facebook users. In the similar context, Androutsopoulos (2013) has shown that the networked multilingual practices of students are genre-shaped, individualized, and relied on stratified and wide repertoires. Park et al. (2016) have found significant gender differences in terms of assertive language and affiliative language, supporting the findings of present study. The findings have also indicated that language features were mostly followed by female Facebook users in an online context. In line with the present study, Shepherd (2016) has revealed that female Facebook users are more intended to prolong their communication with colleagues and; therefore, chose different patterns when writing or chatting with these colleagues. Tifferet $\&$ Vilnai-Yavetz (2014) have supported the findings of present study have discussed that there is a positive and significant gender differences in the context of language features and self-representation. Alm (2015) has revealed that writing experiences on Facebook was perceived to be useful for the formal language writing context, suggesting the need for connecting strategies between formal and informal writing environments.

The findings of the present study have shown that Facebook users socially interact with family and friends and spend more time communicating using Facebook. Similar to the present findings, Perju-Mitran \& Budacia (2015) have suggested that gender differences communicate with promotional messages and respond to them, with essentials for the online environment and offer its interactive attributes. However, both studies were failed to found negative effects of Facebook messages and communication on academic performance. Sheldon (2015) also offered similar viewpoints that Facebook users aimed to add their educators as friends for knowing them better on a personal level. This has been a new aspect in understanding the communication behavior of students when interacting with their educators or professors, which lacks in this study. The study has further emphasized that the male students were more communicative as compared to the female students, opposing the findings of Brouer et al. (2017). Chan et al. (2015) have indicated that communication behavior and patterns play a pivotal role in determining students' satisfaction with Facebook for male users. However, female users are more inclined toward relationship maintenance to determine the user satisfaction with Facebook. Alhabash \& Ma (2017) have shown that Facebook users spent almost most of the time in communicating and interacting with other students, family, and friends.

\subsection{Theoretical Implications}

The important contribution of this study is that it understands the communication behaviors, language features, and social behaviors on the gender differences that exists between Arabic Facebook users. This was an area in which no or few studies have been conducted in the context of Jordan. The findings of this study are also supported with the findings of the previous studies carried out in a different geographical setting (Aljasir et al., 2017; Biernatowska, Balcerowska, \& Bereznowski, 2017; Kasuma, 2017) regarding how communication behaviors and language features of Facebook users differentiate gender perspectives.

In addition, this study has ascertained that female enrolled as Facebook users tend to communicate and interact with their colleagues, family, and friends. However, the specific finding was in contrast with previous studies, 
which found that there was a significant difference in the perspectives of Arabic users (Brouer et al., 2017; Thompson \& Lougheed, 2012). Lastly, the findings of this study will help to further the understanding of patterns based on communication behaviors, language features, and social behaviors on gender differences of Facebook users as a population group. The study enlarged into the understanding of Facebook as an online platform from the perspectives of Jordanian users. This filled a gap that exists concerning Facebook users in Jordan.

\subsection{Limitations}

In precise, the study has found significant impact of communication behavior, language features, and social behavior on gender differences undertaking the Jordanian Facebook users. However, the study has found several limitations. Firstly, the study has considered only Facebook users for understanding the gender-associated behavior. The study has randomly selected Facebook users who spend most of the time using specific online platform. Secondly, the sample of the study was limited to 270 participants only based on one geographic region. Thirdly, cross-sectional design has been used in this study, which allows the researcher to examine the cause and effect aspects of conceptual framework. Fourthly, the study has proposed the conceptual framework with only 3 constructs, which can be extended for better findings. Lastly, the study has been conducted in only one region; Jordan. Despite of aforementioned limitations, the study has found significant understanding of the gender-associated behavior on Facebook.

\section{Conclusion}

This study has hypothesized that there is a positive and significant impact of communication behavior, social behavior, and language features on gender differences by understanding the gender-associated behavior on Facebook. Strategies can be recommended to assist not only the individuals but also to service providers in an online platform using the findings of this study. The study confirms the popularity of Facebook as an outlet of psychological and social expression for gender-associated behavior in the context of Jordan. The study has found that female users tend to communicate and interact with their family and friends and; thereby, their language features were more improved as compared to male users. Further research has to be conducted to make it possible to arrive at conclusions that are generalizable to the overall population of Jordan. In addition, future studies should focus on a larger sample size and geographical region to provide a broader visualization of the study context. By undertaking exploratory research design, future studies can understand the patterns associated to gender-associated behavior on online platforms in the context of Jordan. Lastly, future studies should assess and understand the study context by including other social networking sites such as Instagram, Twitter, WhatsApp, and Pintrest.

\section{Acknowledgements}

The author is very thankful to all the associated personnel in any reference that contributed in/for the purpose of this research. Further, this research holds no conflict of interest and is not funded through any source.

\section{References}

Alhabash, S., \& Ma, M. (2017). A Tale of Four Platforms: Motivations and Uses of Facebook, Twitter, Instagram, and Snapchat among College Students? Social Media + Society, 3(1), 205630511769154.

Aljasir, S., Bajnaid, A., Elyas, T., \& Alnawasrah, M. (2017). Users' Behaviour on Facebook: A Literature Review. International Journal of Business Administration, 8(7), 111. https://doi.org/10.5430/ijba.v8n7p111

Alm, A. (2015). Facebook for informal language learning: Perspectives from tertiary language students. The EuroCALL Review, 23(2), 3. https://doi.org/10.4995/eurocall.2015.4665

Androutsopoulos, J. (2013). Networked multilingualism: Some language practices on Facebook and their implications. International Journal of Bilingualism, 19(2), 185-205. https://doi.org/10.1177/1367006913489198

Biernatowska, A., Balcerowska, J. M., \& Bereznowski, P. (2017). Gender differences in using Facebook-preliminary analysis.

Broadband Commission. (2013). Doubling Digital Opportunities-enhancing the inclusion of women \& girls in the Information Society. ITU and UNESCO: Geneva.

Brouer, R., Stefanone, M., Badawy, R., \& Egnoto, M. (2017, January). Gender (In) Consistent Communication via Social Media and Hireability: An Exploratory Study. In Proceedings of the 50th Hawaii International Conference on System Sciences. 
Chan, T. K., Cheung, C. M., Shi, N., \& Lee, M. K. (2015). Gender differences in satisfaction with Facebook users. Industrial Management \& Data Systems, 115(1), 182-206. https://doi.org/10.1108/IMDS-08-2014-0234

Cho, E., Myers, S. A., \& Leskovec, J. (2011). Friendship and mobility: user movement in location-based social networks. In Proceedings of the 17th ACM SIGKDD international conference on Knowledge discovery and data mining (pp. 1082-1090). ACM. https://doi.org/10.1145/2020408.2020579

Dino, C., \& Gustilo, L. (2015). Digitalk: An exploration of the linguistic features of CMC. International Journal of Languages, Literature, and Linguistics, 1(1), 51-55. https://doi.org/10.7763/IJLLL.2015.V1.11

Joiner, R., Gavin, J., Brosnan, M., Cromby, J., Gregory, H., Guiller, J., \& Moon, A. (2012). Gender, internet experience, internet identification, and internet anxiety: a ten-year followup. Cyberpsychology, Behavior, and Social Networking, 15(7), 370-372. https://doi.org/10.1089/cyber.2012.0033

Kasuma, S. A. A. (2017). Four Characteristics of Facebook Activities for English Language Learning: A study of Malaysian University Students' Needs and Preferences. Advances in Language and Literary Studies, 8(3), 155-171. https://doi.org/10.7575/aiac.alls.v.8n.3p.155

Kaya, T., \& Bicen, H. (2016). The effects of social media on students' behaviors; Facebook as a case study. Computers in Human Behavior, 59, 374-379. https://doi.org/10.1016/j.chb.2016.02.036

Men, L. R., \& Muralidharan, S. (2017). Understanding Social Media Peer Communication and OrganizationPublic Relationships: Evidence from China and the United States. Journalism \& Mass Communication Quarterly, 94(1), 81-101. https://doi.org/10.1177/1077699016674187

Morris, E. (2013). She'Likes' it, He Doesn't: Gender Differences in Facebook Communication Behaviors.

Muscanell, N. L., \& Guadagno, R. E. (2012). Make new friends or keep the old: Gender and personality differences in social networking use. Computers in Human Behavior, 28(1), 107-112. https://doi.org/10.1016/j.chb.2011.08.016

Park, G., Yaden, D. B., Schwartz, H. A., Kern, M. L., Eichstaedt, J. C., Kosinski, M., ... Seligman, M. E. P. (2016). Women are Warmer but No Less Assertive than Men: Gender and Language on Facebook. PLOS ONE, 11(5), e0155885. https://doi.org/10.1371/journal.pone.0155885

Paul, T., Puscher, D., \& Strufe, T. (2015). The User Behavior in Facebook and its Development from 2009 until 2014. arXiv preprint arXiv:1505.04943.

Perju-Mitran, A., \& Budacia, A. E. (2015). Gender Differences in Modeling the Influence of Online Marketing Communication on Behavioral Intentions. Procedia Economics and Finance, 27, 567-573. https://doi.org/10.1016/S2212-5671(15)01034-5

Psylla, I., Sapiezynski, P., Mones, E., \& Lehmann, S. (2017). The role of gender in social network organization. PloS one, 12(12), e0189873. https://doi.org/10.1371/journal.pone.0189873

Santamaría-García, C. (2013). The Discourse of Social Networking Sites in University Students' communication with Their Peers. Revista Española de Lingüistica Aplicada, 123.

Schmitt, D. P., Realo, A., Voracek, M., \& Allik, J. (2008). Why can’t a man be more like a woman? Sex differences in Big Five personality traits across 55 cultures. Journal of Personality and Social Psychology, 94(1), 168. https://doi.org/10.1037/0022-3514.94.1.168

Sen, N. (2016). The discourse analysis of Facebook and its impact on language learning: a study (Doctoral dissertation, BRAC University).

Sheldon, P. (2015). Understanding students' reasons and gender differences in adding faculty as Facebook friends. Computers in Human Behavior, 53, 58-62. https://doi.org/10.1016/j.chb.2015.06.043

Shepherd, R. P. (2016). Men, women, and Web 2.0 writing: Gender difference in Facebook composing. Computers and Composition, 39, 14-26. https://doi.org/10.1016/j.compcom.2015.11.002

Stopczynski, A., Sekara, V., Sapiezynski, P., Cuttone, A., Madsen, M. M., Larsen, J. E., \& Lehmann, S. (2014). Measuring large-scale social networks with high resolution. PloS one, 9(4), e95978. https://doi.org/10.1371/journal.pone.0095978

Thompson, S. H., \& Lougheed, E. (2012). Frazzled by Facebook? An exploratory study of gender differences in social network communication among undergraduate men and women. College Student Journal, 46(1), 8898. 
Thurairaj, S., Hoon, E. P., Roy, S. S., \& Fong, P. W. (2015). Reflections of Students' Language Usage in Social Networking Sites: Making or Marring Academic English. Electronic Journal of e-Learning, 13(4), 302-316.

Tifferet, S., \& Vilnai-Yavetz, I. (2014). Gender differences in Facebook self-presentation: An international randomized study. Computers in Human Behavior, 35, 388-399. https://doi.org/10.1016/j.chb.2014.03.016

Vevere, V. (2015). Impact of social media on interpersonal communication patterns. Societal Studies, 7(1), 124138.

Wood, J. (2012). Gendered lives. Nelson Education.

\section{Appendix A}

Questionnaire/ إستبيان

\section{Section A}

\begin{tabular}{ll}
\hline Gender/ أجنس Male/ أنثى & \\
& Female/ \\
\hline Age/العمر & $15-20$ \\
& $21-25$ \\
& $26-30$ \\
& $31-35$ \\
& $36-40$ \\
\hline
\end{tabular}

\section{Section B}

\begin{tabular}{|c|c|c|c|c|c|c|}
\hline & & 1 & 2 & 3 & 4 & 5 \\
\hline & & $\begin{array}{l}\text { Strongly } \\
\text { disagree/ } \\
\text { واوبدة } \\
\text { وبشة }\end{array}$ & لاأو افق/Disagree & محايد/Neutral & أو افق/Agree & $\begin{array}{l}\text { أو افق / Strongly } \\
\text { agree }\end{array}$ \\
\hline \multicolumn{7}{|c|}{ سلوك التواصل Communication behavior سلت } \\
\hline $\begin{array}{l}\text { السؤال الأول } \\
\text { CB1 }\end{array}$ & 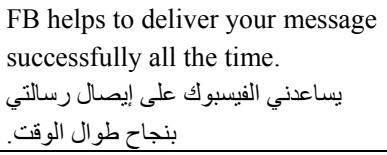 & & & & & \\
\hline $\begin{array}{l}\text { CB2 } \\
\text { السؤال الثاني }\end{array}$ & $\begin{array}{l}\text { FB helps to convey your } \\
\text { thoughts easily. } \\
\text { يساعدني الفيسبوك على أفكاري } \\
\text { بسهولة. }\end{array}$ & & & & & \\
\hline 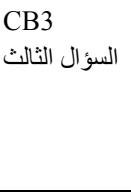 & $\begin{array}{l}\text { FB is a good platform to } \\
\text { communicate and connect with } \\
\text { your friends and family } \\
\text { العتبر الفيسبوك مكان للتحدث والإتصال مع العائة. }\end{array}$ & & & & & \\
\hline 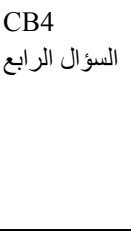 & 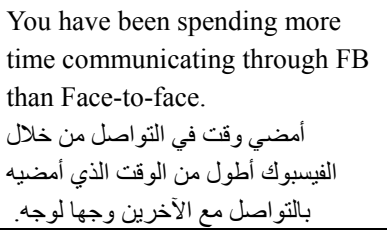 & & & & & \\
\hline \multicolumn{7}{|c|}{ الخصائص اللغوية/Language Features الخصاية } \\
\hline 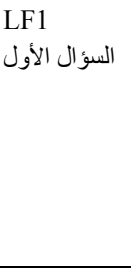 & 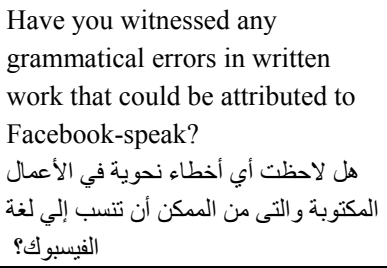 & & & & & \\
\hline
\end{tabular}




\begin{tabular}{|c|c|}
\hline $\begin{array}{l}\text { LF2 } \\
\text { السؤال الثاني }\end{array}$ & 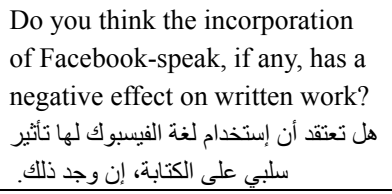 \\
\hline $\begin{array}{l}\text { LF3 } \\
\text { السؤال الثالث }\end{array}$ & 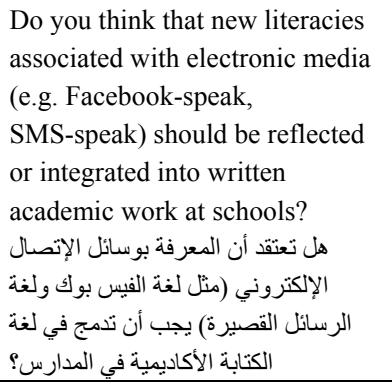 \\
\hline 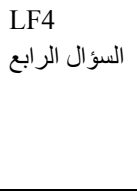 & 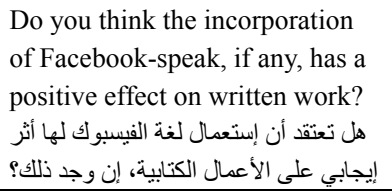 \\
\hline \multicolumn{2}{|c|}{ Gender Patterns/ الأنماط المتعلقة بالجنس } \\
\hline $\begin{array}{l}\text { GP1 } \\
\text { السؤال الأول }\end{array}$ & $\begin{array}{l}\text { I use Facebook to share } \\
\text { information and resources with } \\
\text { my friends. } \\
\text { أستخدم الفيسبوك لمشاركة المعلوماتئ مع المصادر مع أصدائي. }\end{array}$ \\
\hline $\begin{array}{l}\text { GP2 السؤال الثاني }\end{array}$ & 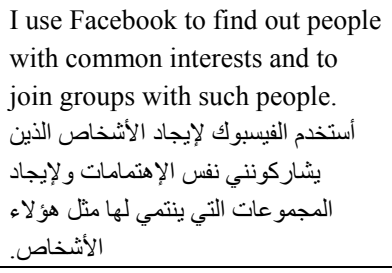 \\
\hline $\begin{array}{l}\text { GP3 } \\
\text { السؤال الثالث }\end{array}$ & 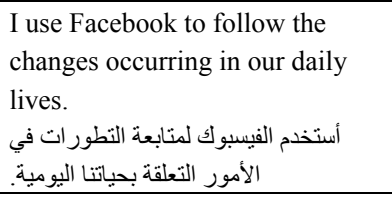 \\
\hline $\begin{array}{l}\text { GP4 السؤال الرابع } \\
\text { الرئ }\end{array}$ & 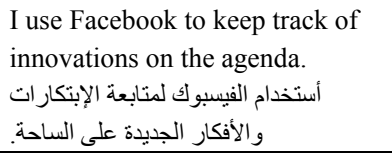 \\
\hline
\end{tabular}

\section{Copyrights}

Copyright for this article is retained by the author, with first publication rights granted to the journal.

This is an open-access article distributed under the terms and conditions of the Creative Commons Attribution license (http://creativecommons.org/licenses/by/4.0/). 